Dorota Filipczak

University of Łódź

\title{
"Alternative Selves" and Authority in the Fiction of Jane Urquhart
}

\section{ABSTRACT}

The article engages with "alternative selves," a concept found in The Stone Carvers by a Canadian writer, Jane Urquhart. Her fiction is first seen in the context of selected texts by Lucy Maud Montgomery, Margaret Laurence and Alice Munro, who explore the clash between female characters' conventional roles and their "secret" selves. My analysis was inspired by Pamela Sue Anderson's A Feminist Philosophy of Religion, which stresses the need for "reinventing ourselves as other" in the face of biased beliefs and dominant epistemology. In particular, my article refers to Anderson's concern with Kant's imaginary from The Critique of Pure Reason, where "the territory of pure understanding" is projected on the island, while desire, chaos and death are identified with the sea. Seen through the prism of a feminist reading of the philosophical imaginary, the sea becomes the female beyond. Urquhart's three novels: Away, The Stone Carvers and A Map of Glass dissolve the opposition between Kantian island and water, by showing how reason is invaded by desire and death, and how the female protagonist embodies the elements that have been repressed. Urquhart's fiction, which is "landscape driven," provides the image of a dynamic relationship between the qualities that form a static binary opposition in Kantian discourse. Mary in Away, Klara in The Stone Carvers and Sylvia in A Map of Glass all subvert the dominant epistemology by following their desire, which becomes "a positive energy" and not "a deviation from a good rational norm," to refer to another concept by Anderson. Urquhart's Mary, Klara and Sylvia have to contend with power vested in collective beliefs and stereotypical construction of femininity. By venturing into the liminal zone beyond the territory of "pure understanding," the three protagonists regain their voices and discover their authority. The article ends with the analysis of a Homeric intertext in A Map of Glass, where Sylvia identifies with Odysseus "lashed to mast" so that he would not respond to the call of the siren song. Reading Homer's passage 
on the siren song, one realizes that the use of the Kantian imaginary turns Ithaca into the island of truth, and the sea into the stormy beyond, identified with desire, death and femaleness. While the Odyssey suppresses the dangerous message of the siren song, Urquhart's fiction rewrites it and reclaims it as positive inspiration for the female protagonist.

\section{Abstract}

In A Feminist Philosophy of Religion Pamela Sue Anderson sets out to refigure biased beliefs and challenges "the dominant epistemology" by stressing the need for "reinventing ourselves as other" (18). The other is understood here in two ways, as "the repressed other of female desire" and "the outsider on the margins of patriarchy." The idea has long been present in literature in a different guise. As many novels of Canadian women writers demonstrate, "the repressed other of female desire" has always sought entry into literary discourse. For example, the trilogy about Emily Byrd Starr by Lucy Maud Montgomery made claim to the erotic and creative potential in a woman controlled by an unimaginative family and patriarchal construction of femininity. Though Emily finally succumbed to the glamour of an idyllic union, she came closest to Montgomery's own yearning to reinvent herself as other. Montgomery identified with her own heroine, whose greatest wish was to become a writer (After Green Gables 88).

The importance of Emily books for Canadian women writers can be seen in Margaret Laurence and Alice Munro. Laurence's Vanessa from A Bird in the House also reinvents herself as a writer. One story in the cycle "The Half-Husky" shows Vanessa receiving an unusual gift from a Ukrainian outsider to the brick house of Grandfather Connor. Vanessa gets a dog of mixed blood, who grows into a fierce creature because he has been taunted by another outsider. The way that animals in this short story cycle exteriorize the nature of people echoes Amerindian stories, as Margaret Atwood observed in her letter to Laurence (2). The half-husky might also be seen as a counterpart of Hesse's Steppenwolf, because he illustrates the fierce, creative urge in Vanessa. This urge cannot be tamed by the smell of floors polished with beeswax, which is disdained by Steppenwolf, and eventually abandoned by Vanessa, when she makes an exit from the world of convention into the world of writing (Filipczak, Unheroic Heroines 291-92).

Laurence's term for the repressed other in a woman was "that other self of hers." The writer used the phrase with reference to her mother in 
Dance on the Earth, in a passage describing her mother's love for music, her artistic self, which was eventually abandoned because she could not reconcile it with wifely and maternal duties (38). "That other self of hers" connects with the underground self in the fiction of Alice Munro, especially Lives of Girls and Women, where the intertwined erotic and creative desires of Del Jordan constitute one of the secrets in "deep caves paved with kitchen linoleum" (210). Del lives a trivial life, but her mind wanders into fiction. And so does her body when she leaves town to make love to Garnet French, who later nearly drowns her in the Wawanash River because she refused to convert to his creed and marry him. Del gothicizes her experiences in the last chapter of her novel, where she reinvents herself as the author of a Gothic text, whose plot disturbingly transforms and completes whatever did not happen to her.

The phenomenon of "that other self of hers" appears in the fiction of Jane Urquhart, who, like Laurence and Munro, acknowledges the importance of the Emily trilogy on her own growth as a writer (Hammill 113). Starting with her first novel Whirlpool, through Away into the latest fiction, Urquhart's female protagonist is the one who challenges the dominant ideology by following her desire. Away is unique in projecting the safe structure of mental habits on an island and turbulent desire on the ocean. This brings to mind the opposition set up by Kant in an image of an island in The Critique of Pure Reason, which is so convincingly explored by Pamela Sue Anderson in A Feminist Philosophy of Religion and in the article from this issue of the journal. Here is an excerpt from the former: "[m]odern, philosophical texts have frequently used images of the sea as outside territory of rationality, in relation to the (rational) secure ground of an island" (xi). In this context, Jane Urquhart's Away can be seen as text that dissolves the opposition in the philosophical imaginary, for the island of Rathlin in the north of Ireland is suddenly deluged by a tidal wave carrying silver teapots, cabbages, barrels of whiskey, and finally a dying sailor from a shipwrecked vessel. The sailor is found by one of the female protagonists, Mary O'Malley, which changes her fate, and the fates of women from the next generations of her family.

An excerpt from Kant's philosophical masterpiece quoted by Pamela Sue Anderson states the following: "the territory of pure understanding ... is an island, enclosed by nature itself within unalterable limits. It is the land of truth-enchanting name! — surrounded by a wide and stormy ocean, the native home of illusion" (qtd. in Feminist Philosophy 11). In the words of the author

Kant uses the sea to represent the danger of false belief and illusion as contrasted with the true beliefs and secure reality of the island. The fem- 
inist objection to the latter is that desire and disorder associated with water and fluidity are feared, while reason and order linked with stability and solidity are highly valued. (xi)

Jane Urquhart's novel certainly ventures into the turbulent sea of desire through the character of Mary who is transformed into the other when the boundary between the island of reason and the ocean of desire collapses as a result of the tide. Urquhart's description of the tide transforming the island and at least one of its inhabitants is not unique in Canadian literature. The Resurrection of Joseph Bourne by Jack Hodgins is set in Port Annie on an island buffeted by the Pacific Ocean in British Columbia, and tells a similar story of a young woman's sexual awakening:

Just when Angela Turner had decided to give up and leave Port Annie, where nothing ever happened to a girl except this never-ending rain that would drive her crazy, the giant wave had washed up into town and left a Peruvian sailor on the flowered sheets of her unmade bed. (41)

In contrast to the sailor who dies in the arms of Mary in Away, this one proves very much alive, elegant and ingenious in the sexual education he offers to the otherwise sexless Angela (a telling name indeed), who enjoys him for quite some time in her isolated house before he finally leaves her in order to join the crew of his ship. In the narrative by Hodgins the wave breaking into Port Annie is connected with many magical events, such as the arrival of an amazingly beautiful woman through whose agency the title character Joseph Bourne is miraculously resurrected. The collapsing of the boundary between the turbulent ocean and the clean, ordered city, now strewn with seaweed and pregnant with change, signals the incursion of magic realism, the mood that also pervades Away. ${ }^{1}$ Both authors talk about the visitation by a tidal wave, the invasion of reason by desire, the transformation of a chosen character by the encounter with the other, who brings in the excluded element of physicality. Both connect nicely with the image from Kant, whose rigid distinction between land and sea they actually dissolve. A question arises about how perceptive an observer of nature Kant actually was. He is known to have spent his life in Königs-

1 For the analyses of Away in the context of magic realism see: Anna Branach-Kallas, In the Whirlpool of the Past: Memory, Intertextuality and History in the Fiction of Jane Urqubart, Toruń: Wydawnictwo Uniwersytetu Mikołaja Kopernika, 2003, 141-152; Maria Edelson, “"The story will take her wherever it wants to go:' Narrative and Landscape in Away," Bringing Landscape Home in the Writings of Jane Urqubart, ed. Dorota Filipczak and Agata Handley, Łódź: Wydawnictwo Uniwersytetu Łódzkiego, 2010, 63-74; Agnieszka Rzepa, Feats and Defeats: Spaces of Canadian Magic Realism, Poznań, Wydawnictwo Naukowe Uniwersytetu im. Adama Mickiewicza, 2009, 73-79, 97-99. 
berg, whose historical centre includes two islands on the river Pregel. Kant only travelled to the places in the vicinity of Königsberg (Reiss xvii). Tidal movement must have made scant impression on him, for the Baltic rises and falls very little in comparison with other seas. In fact, Kant's distinction between land and water may have been influenced by the river islands on the Pregel. Let us quote an excerpt from Away describing what happens on the island of Rathlin, a parodic echo of Kant's northern island, which lies off the most northern coast of Ireland:

The night before a furious storm had reduced the circumference of the island by at least ten feet. It had snatched overturned curraghs from the shore and dispatched seven of Mary's favourite boulders to God knows where. The sandy beach nearest the girl's cabin had been made off with as well and had been replaced with a collection of stones resembling poor potatoes. No one-not even those who had spent some time on mainland beaches-had seen their like before and they were rumoured to have come from the land where no grass grew and nothing breathed. (4)

Commenting on Kant's image, Pamela Sue Anderson raises the question of the relation between a female philosopher and the sea from Kantian imaginary (Feminist Philosophy 12). I shall borrow this question in order to apply it to the female character in Urquhart's fiction and her relation to the Kantian ocean, whose mediator she becomes on the island of supposed truth.

Urquhart's Mary O'Malley is believed to have been taken "away" in a mysterious way, becoming forever an outcast from the community, despite its unremitting efforts to socialize her back into her conventional role. In Mary's case, "that other self of hers" (to use Laurence's phrase) is a gift from the dying sailor who kindles enough love in her to estrange her from the community. Mary is the mediator between stability and order on the island and turbulence of the ocean, which submerges the ship called Moira and its sailor who utters the name of the ship in front of Mary, thus changing her identity for ever. Mary swims naked in the ocean with her demon lover, and imagines sexual union. He introduces her to the world of submerged structures, sunken architecture, attributes of life on the land now buried in the sea of desire. Caterina Ricciardi draws readers' attention to the fact that Mary recognizes the sailor as a visitor from the "otherworld island." The critic asks if Canada, where Mary is taken away in the literal sense much later, becomes "Oisin's or Saint Brendan's isle to be searched for in the west, across the sea, far away from Ireland" (70). This interpretation would further destabilize the Kantian opposition between island and ocean. The island of Rathlin has its "otherworld" opposite, while Canada turns into a mythical Irish isle, as if each of them had its doppelgänger. Ricciardi's comment hints at the motif of descent, which 
is also noted by Anne Compton, who compares the condition of Mary to that of Persephone, who "will live in this world and in the otherworld" (135). While Persephone connects death and desire, the descent "under water" also brings to mind "the waters of death" in biblical Sheol, a perilous experience that may but does not have to be a prelude to regeneration (Filipczak, Valley 48-49). This, in turn, connects with the descent into "that other self of hers" or "underground self," a necessary catalyst in the metamorphosis of other Urquhart heroines.

The name and Irish context of the protagonist of Away cannot but provoke associations with Mariolatry. Mary is a virgin, though she gains complete knowledge of a male body from her single act of watching over the dying sailor. Thus she is at the same time pure and possessed by the other, and, characteristically, she ends up handed over to a man who wants to marry her, though, like New Testament Joseph, he knows she has belonged to the other. Mary is an unusual echo of biblical Mary because she is endowed with the gift of eloquence. Rather than pray, she sings the rhymes that provoke the suspicion of a priest, who is willing to "thrash" the demon out of her if necessary. Mary's refusal to go back to her former self finds a most interesting expression in the scene that might be read as a reversal of Annunciation. In order to free her from her demon lover, Father Quinn tries to exorcize Mary repeatedly in the presence of her mother and her future husband. He resorts to all possible means at his disposal: prayer, holy water, psychological pressure. Mary comes up with one word that is relevant in the context:

"No," she said quietly, and it was the first word she had spoken.

"No," she said again into the distance of the room.

"Cast off this shadow, Mary," the priest was saying "that stands between yourself and God." (Away 48)

Pressure of ecclesiastical authority, which is supposed to transform Mary into God's handmaid, fails to elicit her agreement, let alone her selfeffacement. Mary stands her ground, and in her thoughts belongs to someone else. Brian marries her, and promises to protect her. Mary's visions disappear when she becomes a mother. In the face of devastating potato famine the couple move to Canada with their son, much like Joseph and Mary fleeing to Egypt. Mary gives birth to a daughter in the new land, symbolically transforming it into the locus of new life. Yet she is later taken "away" again, after she comes into contact with a vast expanse of water. On that memorable day her son Liam sees her apron flapping on a clothesline in the wind. The apron is the costume connected with the role that Mary never fully identified with, so she was able to discard it. 
In the words of Anna Branach-Kallas, Mary is "the doubly colonized other." As she notes, Mary's husband

... who has always sought for a Celtic bard among his students and is filled with sorrow because he has never found one, which makes him fear that Gaelic culture will disappear, fails to notice that he has given his learning to a real poet—his wife. (138)

Branach-Kallas sees Mary as challenging the stereotypes of Irish peasant women and Canadian pioneer women. In the latter form Mary resembles the first of Urquhart's fictional heroines, Fleda McDougal, who writes herself out of the military, nationalistic and domestic scripts that her husband Major McDougal prepared for her. Fleda is trapped in the image of an angel in the house, and in a fantasy of femininity spawned by a poet who adores her, but she resists both. Her journal, whose final words reveal her voice, might be seen as a reconstruction of écriture feminine in nineteenth-century Canada. It ends with the words "[s]etting forth," which encapsulate the condition of Urquhart's heroines: setting forth from the islands of objective "truth," following their own subjective desire for potential that can be found only beyond the secure confines.

In her novel explicitly dealing with a female artist, The Stone Carvers, the author shows us a protagonist who also yearns to reinvent herself, but, like the previously mentioned female characters, she is confined in the homely structure of custom and propriety. A descendant of German immigrants to Ontario, Klara Becker lives an orderly life in the village of Shoneval until her peace of mind is disrupted by the intrusion of an Irishman, Eamon O'Sullivan, who falls in love with her.

One of the scenes describing his courtship of Klara claims particular attention.

That night as she teetered on the edge of sleep, Klara heard music so achingly sad, so astonishingly pure and clear, that her entire body was alert to the sound. She walked furtively over to the window, as if she feared she might awaken a number of unfamiliar ghosts or alternative selves. (86)

The quotation leads us into "the territory of dreams and memory ... a milieu in which Urquhart excels," to use the words of Timothy Findley from his review of Storm Glass (14). Klara guesses that the "music so achingly sad" is the sound of the fiddle played by Eamon in the orchard, and "her entire body" is "alert." At the same time she is caught in a Gothic situation. Her erotic desire manifests itself as a taboo, a Gothic secret whose presence she fears to acknowledge because it might destroy 
her conventional image. Her desire must appear fearsome to her because she has interiorized male disapproval of female expressiveness. As stated by Anderson in her comment on Kristeva, female desire "has a negative meaning for patriarchy; in the patriarchal configuration of Adam and Eve, it is a conscious inclination to deviate from a good rational intention" (Feminist Philosophy 151). Klara cannot reach for her potential, because she has not yet accepted her "alternative selves." She can only experience her sexual drive "furtively" and "on the edge of sleep," but "the following morning she had almost convinced herself that the music and the figure in the orchard had been merely an unsettling dream" (Urquhart, The Stone Carvers 86). Interestingly, the night scene recalls Mary O'Malley's communion with the demon lover. His "song was like no other song," and it became a source of forbidden knowledge, somatic and spiritual.

Eamon challenges Klara's desire for "passion and imagination" (99), which has been subdued by the Sisters of the Immaculate Conception who attempted to transform their protégée into a docile handmaid. Klara is described as the one who would like to know the secret lives of saints, especially "moments of sin." Thus she is "alert" to "alternative selves" underneath the facade. This is exactly why the nuns try to divert her attention from martyrs and visionaries to abbesses, connected with hard work, as a way to ward off temptation. In a very ironic passage the text intimates to us how the nuns try to prevent "Klara's idle hands" from becoming "the Devil's playground" (100). Indeed, Klara is very conscientious in her role as seamstress, and as woodcarver working on the figure of an abbess for the local church. What the nuns do not foresee is that Klara will not be prevented from discovering her "alternative" self, which will inevitably emerge as a result of her passion for Eamon. Her "idle hands" explore Eamon's body only "furtively" at first, when she takes measurements for his red waistcoat. Later the same "idle hands" sculpt Eamon's face in Walter Allward's monument dedicated to soldiers killed in the First World War.

While she is taking measurements, which is an erotic overture to the relationship, Eamon declares his passion for her, and she finds herself responding in kind. Eamon voices his desire for a red waistcoat, and does not change his mind when Klara chastises him for a flashy colour. His passion for her is voiced with equal intensive way. Her mind fraught with images of black, grey and white garments, a black book of measurements in her hand, Klara is both repelled and attracted by the explicitness of desire. "I'll die of this" (80), Eamon declares. His image of agony through love connects with Klara's grandfather's allusion to passionate Irish saints, which he made in response to her question: "Would my abbess ever have been in love?” (100). If the abbess is seen as Klara's self-portrait, it is essential for her to ask such a question. 
Interestingly, Klara Becker and Eamon O'Sullivan can be juxtaposed with Gretta Conroy and Michael Furey in "The Dead," the last short story in James Joyce's Dubliners. Michael Furey, of whom Gretta says: "I think he died for me" (252), is as passionate as Eamon. The couple go for walks in the country just like Eamon and Klara. Michael stands under Gretta's window to confess his love, much like Eamon, whose "nocturnal appearances" delight Klara. And Michael has a good voice; when Gretta hears Bartell D'Arcy sing after the party at Gabriel's aunts she seems mesmerised by "distant music" (Joyce 240), which makes both Michael Furey and her "alternative" self resurface from memory in the confession she makes later in front of her husband, Gabriel. An association that suggests itself at this stage is that the music Eamon made in the orchard on a memorable night lingered in Klara "on the edge of sleep," and Eamon's memory beckoned her from distance many years later. After a fruitless existence in Shoneval, her time filled with tending a bull and cow, Klara becomes aware again of her "alternative selves" of artist and lover.

Klara has travelled across the ocean in male disguise, apt for her artistic vocation, and thus has managed to become one of the carvers working on the war memorial. Her real identity is unmasked by Walter Allward, when she is altering one of his figures. It is then that her companion Giorgio falls in love with her. Klara eventually confesses Eamon's name in front of him, like Gretta, who voiced Michael Furey's name in front of Gabriel. Yet Gabriel could only feel humiliated by Gretta's passion for a man who had worked "in the gasworks," whereas Giorgio lets Klara mourn Eamon.

Klara's alteration of Allward's monument can be called female dialogue with a tradition ${ }^{2}$ that Allward stands for. Allward's previous work is the sculpture of colonial founding fathers, hence a heavily paternalistic statement. The marble for the war memorial is cut by his engineers in the very quarry that served emperor Diocletian, which connects Allward with the Roman Empire while continuing the link with the British Empire inherent in his earlier project. The difference between him and Klara is like that between a male philosopher and his feminist interpreter. Allward wants the universal in the monument, but Klara makes the sculpture singular, drawing on her embodied experience of sexual love. Her vision is accommodated by the sculptor, and thus it becomes a personal inscription on an otherwise impersonal body of work. Alana Vincent says: "Urquhart chose the figure with the least visible face of any on the monument onto which to project her own narrative" (80). Urquhart's novel is a monument

2 Cf. Michèle Le Doeuff, "Women in Dialogue and in Solitude," Journal of Romance Studies 5:2 (2005): 1-15. 
in itself, and a dialogue with the tradition of war heroism, whose revisionary interpreter she becomes.

In the act of chiselling Eamon's features on the monument designed by Allward, Klara reverses the myth of Pygmalion; she symbolically recreates Eamon, and also realizes herself as an artist. This echoes her previous work on the red waistcoat, which she recreated for herself after Eamon's death. Like Ishtar braving the underworld to reach for Tammuz, like Isis restoring dismembered Osiris to life, Klara re-members Eamon. Other critics also connect her descent into the trenches with myth. Branach-Kallas sees Klara as Euridyce, who is led from the world of shadows into light by Giorgio, her Orpheus ("Gothic Palimpsests" 49). Ann Compton states that "like the figures of Greek myth [Klara] descend[s] into a lower world as Euripides' Alcestis does when she offers herself to Hades as a substitute for her husband ... or as Ariadne does to guide Theseus out of the labyrinth" (139). While I do not find Compton's interpretation convincing, it is evidence that Jane Urquhart's fiction resonates with allusions to mythology and the classics, and this I shall return to later.

Female desire is certainly the focus of Away and The Stone Carvers. Interestingly, a passage from The Stone Carvers might be used to comment on the condition of the protagonist in Away. When Klara ponders the lives of saints and other stories that the Sisters of the Immaculate Conception tell her for moral guidance, she comes up with the following:

She believed (even more heretically and secretively) that the Virgin Mary had been in love with the Holy Spirit, and that she had spent the remainder of her days pining for this spirit and longing for another miraculous union. (99)

The text contains a trace of Away, and confirms my interpretation of Mary's condition. Though she is Virgin Mary à rebours, Mary O'Malley pines for another miraculous union all her life and does not rest until the union is consummated in her own death. Klara's Virgin Mary turns out to be a passionate woman like all female characters in Jane Urquhart's fiction. Klara endows the Virgin Mary with the sexual desire that was stamped out or duly removed from her image under Christian patriarchy.

The imagery of the novel is reminiscent of Away. When Klara and Eamon fall on the ice together and their hands touch, she is still frozen into her conventional role. Yet when Eamon startles her into eroticism during a ritual of taking measurements, Klara seems "to be moving in a dream through water" (80; my emphasis). Also, like Patrick in The Whirlpool, and the sailor in Away, Eamon is a beautiful young man, which Klara notices when they both, though separately, undress in order 
to swim chastely in the pool. The scene also anticipates their conjunction intertextually, because water is the element of Mary swimming out naked to merge with her demon lover. At the same time, the seascape conjured up in Urquhart's novels invites comparison with Elemental Passions and Amante Marine by Luce Irigaray. Away brings in the repressed element of water which transforms solid land. Water flows its surreptitious course in The Stone Carvers, where it surfaces to dissolve the solidity of the land on which the monument stands, in particular, the tenuous solidity of the underground corridors, into which Giorgio and Klara descend in order to make love in the face of death, thus enacting the sentence in the last chapter of the Song of Songs: "love is strong as death." The military structure is suddenly invaded by desire: "she believed her body, the candlelight, and the walls of the tunnels were all turning to water, and that she might drown in herself, in him" (355). Later, after the love scene, Giorgio and Klara are described as explorers travelling a "river system they had yet to name" (356). This time the Kantian opposition between land and watery expanse is undercut in a different way. The portion of land given to Canadians in return for their action in war becomes an island whose base dissolves in the "tributaries" of hidden passageways. The only solid structure seems to be Allward's monument, which reaches into the air and merges with it. There is a subtle allusion to Away here, and reversal of its imagery. Mary O'Malley is led by her demon lover to admire the underwater structure, a city in the ocean; Klara is led by Giorgio and "his light" to discover a network of tunnels built during the First World War like an underground river system, where walls turn to water. Both images collapse the opposition between fluid water and solid earth.

Water imagery keeps resurfacing in Urquhart's A Map of Glass, where the reader encounters an island whose geographical identity is contested. Some consider it a river island, while others see it as an island on the lake whose waters merge with those of the river. Known as Timber Island, it was inhabited by Andrew Woodman's ancestors. They had drained the bog in the area so successfully that the land began to lose water. Sand crept into the houses, slowly seeping into kitchen utensils and beds, to finally pile up in the windows, cutting off sunlight and air. Reversing the imagery connected with the monument and its surroundings in The Stone Carvers, the text shows how the island washed by waters becomes, paradoxically, a desert. Seen as a metaphorical comment on the Kantian island of truth, Timber Island reflects the condition of the mind that has excluded desire and chaos as represented by vanished water. The condition of the island is embodied in its sole occupant, a middle-aged spinster artist, Annabelle. Her exclusion of desire consigns her to a life of dryness, practicality and routine. In her essay on A Map of Glass Marta Goszczyńska interprets Annabelle 
and other characters through the prism of the novel's intertextual link to Tennyson's "The Lady of Shalott" "Cursed Islands" 93-105). In fact, Tennyson's river island could easily be combined with the Kantian land of truth and enchantment washed by the waters of death.

This is what we find at the beginning of the novel, where Jerome seeks inspiration for his art in the total solitude of deserted Timber Island, now covered with snow. Yet Jerome's feeling of security is suddenly shattered by the sight of "a drowned man," "a floater," to use a word from The Whirlpool, where Niagara Falls and its vicinity become the scene of spectacular tragedies, suicides and exploits that end in death. Death encroaches upon the artist's isolation, while he tries to retain the purity of contemplative experience, much like St Jerome, to whom he is compared. This Gothic visitation opens an alternative script to Jerome, the text of desire, which displaces his own narrative. After his return to Toronto he is visited by Sylvia, who claims to have been the drowned man's lover. She shares the story of her desire with Jerome. And, she shares the journals connected with Andrew's ancestors from Timber Island, thus making the "floater" regain his voice. Reverting to the Song of Songs, Sylvia speaks of her love in the face of death, much like Mary O'Malley.

When Sylvia's husband, a doctor, finds her and has a conversation with Jerome, he explains that his wife does not distinguish between hallucination and truth. The man she described as her lover was an Alzheimer's patient who had wandered off on his own in winter, and eventually died. Malcolm's testimony throws light on Sylvia's condition. Sylvia becomes a different person during flights from her ordinary life, and she creates genuine relationships for herself in lieu of the missing sexual connection with her own husband. Malcolm's clinical judgement is distorted by his trust in reason and distrust of imagination. His insistence that Sylvia cannot make friends contradicts the reality of her experience with Jerome and Myra.

The "alternative self" in A Map of Glass echoes and transforms a similar phenomenon in Away. Sylvia is also "taken away" from her ordinary self, but as she is a twentieth-century heroine, her condition is diagnosed medically, unlike the condition of Mary, who, for superstitious nineteenthcentury Irish people, was simply possessed by an evil and recalcitrant spirit, much like the Gerasene demoniac from the Markan Gospel. Sylvia confesses to Jerome the story of her "secret" self, to use the adjective from the novel. Like Mary, she discards her "previous self," to use the expression from Away. The two phrases highlight Urquhart's preoccupation with "alternative selves" which allow female protagonists to venture into dream and desire of more substance than reality controlled by reason.

In conversation with Jerome Sylvia says that she was saved from being run over when Andrew Woodward got hold of her. She conjures up the 
image of Andrew holding her, which brings to mind Mary and the demon sailor whom she holds close to herself. While reminiscing about the later stages of her relationship, Sylvia says:

The idea of him, you see, kept its arm around my shoulders, just as my peninsula kept its arm around the lake, protected me, and kept me safely distant from everyone else. The distance, of course, was not new, but the phantom encircling arm was a surprise until it became a habit like breathing, or like pulse. (134)

The language Sylvia uses combines the Gothic with the somatic. She describes her lover as a phantom, this making him close to Mary's demon lover. The quotation brings to mind Mary swimming naked in the sea until the idea of her lover took shape in the water and she felt herself being entered by him.

Sylvia makes tactile maps, which are substituted for the body in her confession. Her lover is the peninsula against which she defines herself in her fluidity as a lake. The water connects the three analysed books; Mary and her lover swim in the ocean; Klara and Eamon indulge in erotic overtures in the shadowed pool; Sylvia is the lake enacting conjunction with the peninsula identified as the lover. The water is a fitting matrix for the emergence of an "alternative self," which surfaces like a foetus from amniotic fluid. This refigures the Kantian binary opposition which leaves no room for either waters of birth or death, Kant keeping land and water apart, and himself safe from the female beyond.

The water imagery guides us into a particularly revealing intertext explored below. Sylvia's confession to Jerome throws light on the condition of other Urquhart heroines. This is what she says about her lover and herself:

He often stood on burning decks of one kind or another when all but he had fled. And I ... I seemed to be constantly lashed to the mast by those who had, for my own safety—or was it for theirs? — tied me there. (128)

At least three allusions may be embedded in this excerpt. The first is connected with a poem by Felicia Hemans, a Victorian poet who glorified domestic ideology (Carlyle 44-45). Jerome remembers the well-known line from the poem that Sylvia alludes to: "the boy stood on the burning deck, when all but he had fled." Another literary allusion concerns Longfellow's The Wreck of the Hesperus which tells the story of a skipper who takes his daughter out to sea and ties her to the mast when storm breaks out. He dies in the storm, and so does his daughter, whose body, still tied to the mast, is found on the shore. Her bondage recalls crucifixion, and since her purity symbolizes the American nation, she becomes 
a foundational sacrifice (Miskolcze 62). Sylvia sees herself and Andrew as victims of the ideology that foisted repressive stereotypes on men and women alike. Yet, hidden beneath the two allusions is the most important image, that of Odysseus, who is lashed to a mast so that he will not be seduced by the siren song.

According to Lillian Doherty, the author of "Sirens, Muses and Female Narrators in the Odyssey", the siren song is a subversive text within the Odyssey, and therefore its power must be contained so that Odysseus may achieve his homecoming (82). Sylvia may be said to personify the condition of Odysseus, bound to leave home and wander aimlessly. In her case the siren song might stand for the lure of "the alternative self," the subversive voice from the uncharted territory beyond the confines of her domestic role. The siren song posits the danger not only to a female version of Odysseus but also to the social order that keeps her "lashed to the mast" for her own safety. This is where A Map of Glass meets Away, where the motif of seduction by a demon lover corresponds to possible seduction by sirens in the Odyssey. Doherty states that sirens belonged with the Greek folk world just like mermaids, underworld demons and other monstrous creatures (82). Mary's demon lover from Away meets all these criteria. He is connected with the underworld, like a mermaid who supposedly stole a fisherman from the island of Rathlin in Away. The demon lover is thus a male counterpart of the sirens, who seduces Mary with his appearance and song. He offers her knowledge, but also subverts social order and ultimately leads Mary to her death in Canada.

Sirens in the Odyssey are connected with seduction that relies on speech (Doherty, "Sirens" 86). In Away Mary is metamorphosed by the first and last word of a dying sailor, and she embraces the word Moira as her new name, signifying the intrusion of an "alternative self" which displaces her "previous" identity. Klara Becker is also seduced by the power of Eamon's passionate speech, a volume of Irish poetry that he asks her to read, and the music he makes in the orchard. Sylvia appreciates Andrew for the intimate knowledge of the land.

In each of the above books the female protagonist reinvents herself as other, by following a desire which has been repressed. Mary, Klara and Sylvia become outsiders who refuse the attraction of safe domesticity, and venture into a liminal zone fraught with the danger of death and the promise of knowledge. In this they change the pattern connected with Odysseus, who has to ward off temptations that would prevent him from coming home. Mary, Klara and Sylvia are transformed by the experiences that might offer a parallel to the siren song. In T.F. Rigelhof's review of The Stone Carvers, predating A Map of Glass, Jane Urquhart is compared to Homer in her "uncanny ability to interweave historical events, legends, 
folk tales, visions, anecdotes, longings and journeys" (54). One could add that she also undercuts and subverts the monumental and heroic elements of Homeric tradition. Commenting on the experience of reading The Stone Carvers, Rigelhof thinks of a student recounting the experience of reading the Odyssey (55). The Odyssey predates the Kantian opposition between secure island and perilous, stormy sea. Reading Homer's passage on the siren song, one realizes that the use of a Kantian imaginary turns Ithaca into the island of truth, and the sea into the stormy beyond identified with desire, death and femaleness. The unexpected surfacing of this intertext in Urquhart's latest novel is connected with a thorough transformation of this episode. As Lillian Doherty reminds us, the Odyssey "can be seen to elide or circumscribe the voices of dangerous females" (Doherty, Siren Songs 63). This is bound to happen since the siren song is viewed and judged from the perspective imbued with the author's patriarchal bias. Seen in the context of Jane Urquhart's writings, the siren song becomes an inspiration for the female protagonist, awakening her hidden potential like "distant music" in Joyce's "The Dead." The myth is thus refigured and metamorphosed, just like the myth of Adam and Eve rewritten by Pamela Sue Anderson with the use of Kristeva and Ricoeur. In such rewriting "desire comes to be recognized as a potentially positive energy" (Anderson, "Abjection" 221). And the Kantian warning against the perils of water, his preference for enchantment offered by the island of truth, are confronted and transgressed. Only through such refiguring and rewriting can the authority of "alternative selves" emerge and last.

\section{Works Cited}

Anderson, Pamela Sue. "Abjection ... the Most Propitious Place for Communication': Celebrating the Death of the Unitary Subject." Bodies, Lives, Voices: Gender in Theology. Ed. Kathleen O'Grady, Ann L. Gilroy and Jeanette Gray. Shieffield: Sheffield Academic Press, 1998. 209-30.

---. A Feminist Philosophy of Religion. Oxford: Blackwell, 1998.

Atwood, Margaret. Letter to Margaret Laurence 18 Jan. 1971. York University Archives and Special Collections. Call No. 1980-001/001(43).

Branach-Kallas, Anna. "Gothic Palimpsests: Exploring Multiple Forms of Haunting in Jane Urquhart's Fiction." Bringing Landscape Home in the Writings of Jane Urquhart. Ed. Dorota Filipczak and Agata Handley. Łódź: Wydawnictwo Uniwersytetu Łódzkiego, 2010. 37-51.

---. In the Whirlpool of the Past: Memory, Intertextuality and History in the Fiction of Jane Urqubart. Torun: Wydawnictwo Uniwersytetu Mikołaja Kopernika, 2003. 
Carlyle, Norma Clarke. Ambitious Heights: Writing, Friendship, Love: the Jerwsbury Sisters, Felicia Hemans, and Jane Welsh. London: Routledge, 1990.

Compton, Anne. "Romancing the Landscape. Jane Urquhart's Fiction." Jane Urquhart: Essays on Her Works. Ed. Laura Ferri. Toronto: Guernica, 2005. 115-46.

Doherty, Lillian Eileen. "Sirens, Muses and Female Narrators in the Odyssey." The Distaff Side: Representing the Female in Homer's Odyssey. Ed. Beth Cohen. New York and Oxford: Oxford University Press, 1995. 81-92.

---. Siren Songs: Gender, Audiences and Narrators in the Odyssey. Ann Arbor: University of Michigan Press, 1995.

Edelson, Maria. “The story will take her wherever it wants to go': Narrative and Landscape in Away." Bringing Landscape Home in the Writings of Jane Urquhart. Ed. Dorota Filipczak and Agata Handley. Łódź: Wydawnictwo Uniwersytetu Eódzkiego, 2010. 63-74.

Filipczak, Dorota. Unheroic Heroines: The Portrayal of Women in the Writings of Margaret Laurence. Łódź: Wydawnictwo Uniwersytetu Łódzkiego, 2007.

---. "The Valley of the Shadow of Death:" Biblical Intertext in Malcolm Lowry's Fiction. Ed. Paul Tiessen. Malcolm Lowry Reviewe 43-44 (Fall 1998-Spring 1999).

Findley, Timothy. "Through the Looking Glass." Books in Canada, June-July 1987. 14.

Goszczyńska, Marta. "Cursed Islands of Solitude: 'The Lady of Shalott' in Jane Urquhart's A Map of Glass." Bringing Landscape Home in the Writings of Jane Urqubart. Ed. Dorota Filipczak and Agata Handley. Łódź: Wydawnictwo Uniwersytetu Łódzkiego, 2010. 93-105.

Hammill, Faye. Literary Culture and Female Authorship in Canada 1760-2000. Amsterdam and New York: Rodopi, 2003.

Joyce, James. “The Dead.” Dubliners. London: Penguin, 1996. 199-256.

Laurence, Margaret. Dance on the Earth: A Memoir. Toronto: McClelland and Stewart, 1998.

Miskolcze, Robin. Women and Children First: Nineteenth-Century Sea Narratives and American Identity. Lincoln: University of Nebraska Press, 2008.

Montgomery, Lucy Maud. After Green Gables: L. M. Montgomery's Letters to Ephraim Weber, 1916-1941. Ed. Hildi Froese Tiessen and Paul Tiessen. Toronto: University of Toronto Press, 2006.

Munro, Alice. Lives of Girls and Women. Toronto: McClelland and Stewart, 1990.

Reiss, Hans Siegbert. Kant: Political Writings. Cambridge: Cambridge University Press, 1991. 
Ricciardi, Caterina. "Away and the Meaning of Colonization." Jane Urquhart: Essays on Her Works. Ed. Laura Ferri. Toronto: Guernica, 2005. 65-77.

Rigelhof, T.F. "Stone Dazzling: The Stone Carvers." Jane Urqubart: Essays on Her Works. Ed. Laura Ferri. Toronto: Guernica, 2005. 51-56.

Rzepa, Agnieszka. Feats and Defeats: Spaces of Canadian Magic Realism. Poznań: Wydawnictwo Naukowe Uniwersytetu im. Adama Mickiewicza, 2009.

Urquhart, Jane. Away. London: Bloomsbury, 2002.

---. A Map of Glass. San Francisco: MacAdam/Cage, 2006.

---. The Stone Carvers. Toronto: McClelland and Stewart, 2001.

Vincent, Alana. "Making Memory Solid: Body, Landscape and Identity in the Canadian National Vimy Memorial and Jane Urquhart's The Stone Carvers." Bringing Landscape Home in the Writings of Jane Urqubart. Ed. Dorota Filipczak and Agata Handley. Łódź: Wydawnictwo Uniwersytetu Eódzkiego, 2010. 75-86. 